\title{
Evaluation of albendazole treatment on coagulation profile in sheep naturally infected with Dicrocoelium dentriticum
}

\author{
Hasan ERDOĞAN ${ }^{1}$, Mehmet GÜLTEKİN ${ }^{1}$, Kerem URAL ${ }^{1}$, Yasin PARLATIR ${ }^{1}$, Adnan AYAN ${ }^{2}$, Songül \\ ERDOĞAN ${ }^{1}$, Serdar PAȘA ${ }^{1}$
}

${ }^{1}$ Adnan Menderes University, Faculty of Veterinary, Department of Internal Medicine, Aydin/TURKEY

${ }^{2}$ Van Yuzuncu Yil University, Faculty of Veterinary Medicine, Department of Genetics, Van/TURKEY

Key Words:
activated partial thromboplastinducts
anthelmintic
fibrinogen
liver fluke
prothrombin

\section{Anahtar Kelimeler:}

aktive edilmiş parsiyel tromboplastin antihelmintik

fibrinojen

karaciğer kelebeği

protrombin

Received: 06.02.2019

Accepted: 19.06.2019

Published Online: 30.06.2019

Article Code: 523108

Correspondence:

H. ERDOGAN

(hasan.erdogan@adu.edu.tr)

\section{ORCID:}

H. ERDOĞAN: 0000-0001-5141-5108

M. GÜLTEKIN: 0000-0002-5197-2403

K. URAL: 0000-0003-1867-7143

Y. PARLATIR: 0000-0002-6210-8979

A. AYAN: 0000-0002-6564-3416

S. ERDOĞGN: 0000-0002-7833-5519

S. PASSA: 0000-0003-4957-9263

\begin{abstract}
The aim of the present study was to evaluate the selected coagulation profile parameters in sheep naturally infected with Dicrocoelium dentriticum and effects of albendazole treatment. For this reason, 34 merino sheep, aged between 1 and 3 years, naturally infected with Dicrocoelium dentriticum were enrolled in the present study. Plasma and stool samples were withdrawn from each animal before and 10 days after treatment and egg per gram feces were evaluated with Mc Master technique. Prothrombin time, activated partial thromboplastin time and fibrinogen levels were determined by semiautomated coagulometer by using commercial test kits before and 10 days after treatment. Noticeable clinical recovery was detected in all animals after albendazole treatment. There were significant differences on prothrombin time and fibrinogen levels $(\mathrm{p}<0.001)$ between treatment intervals. In conclusion, this is the first study for selected coagulation parameters before and after albendazole treatment for ovine patients naturally infected with Dicrocoelium dentriticum. It should be mentioned that the treatment resulted in lower prothrombin time and fibrinogen values, suggesting that dicrocoeliasis might alter coagulation profile and possibly induce an acute phase response. Furthermore, the clinical relevance in ovine medicine and related results possibly interacting to human medicine has to be determined by future studies.
\end{abstract}

\section{Dicrocoelium dentriticum ile doğal enfekte koyunlarda albendazolün pıhtılaşma pro- fili üzerine olan etkisinin değerlendirilmesi}

\begin{abstract}
ÖZ
Bu çalışmanın amacı, Dicrocoelium dentriticum ile doğal olarak enfekte koyunlarda albendazolün seçili prhtılaşma parametreleri üzerine etkilerinin değerlendirilmesidir. Bu amaçla çalışmaya Dicrocoelium dentriticum ile doğal enfekte 3-6 yaşları arasındaki 34 merinos ırkı koyun dahil edildi. Her hayvandan sağaltım öncesi ve sağaltımdan 10 gün sonra plazma ve dışkı örnekleri alınarak gram dışkıdaki yumurta saçılımı Mc Master tekniği ile değerlendirildi. Protrombin zamanı, aktive edilmiş parsiyel tromboplastin zamanı ve fibrinojen düzeyleri, sağaltım öncesi ve sağaltımdan 10 gün sonra ticari test kitleri kullanılarak yarı otomatik koagülometre ile belirlendi. Albendazol uygulamasından sonra tüm hayvanlarda belirgin klinik iyileşme tespit edildi. Protrombin zamanı ve fibrinojen düzeyleri arasında sağaltım öncesi ve sonrasında önemli farklılıklar $(\mathrm{p}<0.001)$ elde edildi. Sonuç olarak bu çalışma Dicrocoelium dentriticum ile doğal enfekte koyunlarda albendazolün sağaltımı öncesi ve sonrasında seçili pıhtılaşma parametreleri üzerine olan etkisinin incelendiği ilk çalışmadır. Çalışmaya göre elde edilen daha düşük protrombin zamanı ve fibrinojen seviyeleri düşünüldüğünde dikrokoliyazisin pihtılaşma profilini değiştirebileceği ve olası akut faz yanıtını tetikleyebileceği akla getirilmelidir. Ayrıca, küçükbaş alanındaki klinik önemi ve beşeri hekimlikteki olası ilişkili sonuçlar gelecekteki çalışmalarla belirlenmelidir.
\end{abstract}

\section{INTRODUCTION}

Dicrocelium dentriticum is a worldwide (Europe, Asia, North Africa and North America) helminth parasite of humans and animals, including ruminants (1). Dicrocoeliasis causes cholangitis and cholangiectasis, while necrotic and haemorrhagic areas in the liver, depending on the severity of the infection, have been described in both natural and experimental studies (2-4). Treatment costs, loss of economic value in the liver after slaughter, and the digestive disorders, have all revealed the importance of the disease of ruminants (4).
Kavanagh et al. (5) determined the complex balance between hepatobiliary disease and pro- and anticoagulation systems in veterinary patients. The liver has a great artitecture between hepatocytes and blood vessels for diminishment of substances. Hepatic injuries can also damage the capillarisation of sinusoids and result in increases in portal tension (6). The liver is the site of production of almost all the coagulation factors and proteins related to fibrinolysis and anticoagulation; acute hepatotoxicity and chronic liver disease can notably affect the hepatic synthesis of these factors. Fibrinogen is a glycoprotein synthesized by the liver and converted to fibrin by thrombin during blood coagulation also protrombine time (PT) and activated partial thromboplastin time (APT'T) are 
widely used for interpreting bleeding tendencies (7).

Within the life span of $D$. dentriticum, parasite flukes migrate through to the biliary duct system without causing pathological alterations in gut wall and liver capsule. The basic pathological alterations in the liver tissue are caused by the mechanical effect of migration through bile ducts and toxic metabolites secreted by the flukes $(3,8)$. Highly pathogenic infections have been observed in humans who inhabit in endemic areas with neurological symptoms and functional hepatobiliary disorders $(9,10)$.

In recent years, with the use of sheep as a models for human cardiovascular diseases, studies on the coagulation profiles of sheep have begun to gain prominence (11). To the authors knowledge, the coagulation profile in sheep infected with $D$. dentriticum has not been well studied and needs to be recognised in both veterinary and human medicine. The aim of the present study was to investigate selected coagulation profile parameters (protrombine time (PT), activated partial thromboplastin time (APTT), and fibrinogen) in sheep naturally infected with $D$. dentriticum.

\section{MATERIAL and METHOD}

Animals. The study protocol was approved by the University of Adnan Menderes HADYEK unit, institutional laboratory animal ethics committee (no: 64583101/2016/198). Informed written consent was obtained from the owner prior to enrolment.

Thirty-four Merino sheep, aged between one and three years, were enrolled in the study. Three of these animals were presented to the Clinics of Veterinary Medicine, University of Adnan Menderes, Aydin, Turkey with a history of inappetence and decreased weight gain. The rest of the animals were examined in the farm. After routine clinical and laboratory investigations $D$. dentriticum oocytes were detected and albendazole (Vermiprazol, Hipra, Turkey) were administered to all animals at a dose of $15 \mathrm{mg} / \mathrm{kg}$ orally for once.

Sample collection and coagulation tests. A total of $3 \mathrm{ml}$ blood samples were obtained from vena jugularis into three percentage sodium citrate tubes which were then sent to related lab. Afterwards plasma was seperated following centrifugation [via $3,000 \mathrm{rpm}$ for $1 / 4$ hours]. Samples were collected from each animal before and 10 days after treatment. The samples were stored at $4^{\circ} \mathrm{C}$ and were measured two hours after collection. Citrated plasma samples were used to determine the levels of PT, APT'T and, fibrinogen by a semiautomated coagulometer (C2000-4, Beijing Precil Health Instrument Co. Semi-Automatic Coagulation Blood Analyzer, China) using commercial test kits (PT, APT'T, and Fibrinogen kit from Long Island Biotec, Shanghai, China) according to the manufacturer's instructions.

PT reaction was based on the tissue thromboplastin and calcium to activate the extrinsic pathway and convert fibrinogen to fibrin. APT'T reaction was added with an activator (ellagic acid) and brain cephalin (partial thromboplastin) was incubated at $37 \mathrm{C}^{\circ}$ for a period of time to activate factors
XII and XI of the intrinsic pathway of coagulation. Then, in the presence of calcium ions, the fibrinogen was converted into insoluble fibrin finally. The time of plasma coagulation after adding calcium chloride measured on the instrument. Fibrinogen measurement was based on the standard Clauss clothing method.

Parasitological evaluation. Faecal samples from each sheep were collected manually from the rectum using a disposable latex glove. Samples were kept on ice (for up to one hour) laboratory examination. The egg per gram of feces (EPG) test was analysed via the McMaster technique. Prior to the study, a total of $4 \mathrm{~g}$ of faeces were mixed with $56 \mathrm{ml}$ of water. The faecal suspension was stabilized for $30 \mathrm{~min}$ at $24^{\circ} \mathrm{C}$. The obtained suspension was drained onto strainer which was forwarded to a novel tube, and a $10 \mathrm{ml}$ tube was filled at most with the filtered suspension. Afterwards the tube was centrifuged for 300 seconds at $1200 \mathrm{rpm}$, and then the supernatant was abolished. Few seconds later and prior to initiating the egg count, $4 \mathrm{ml}$ of mixture (saturated sodium chlorure with $500 \mathrm{gr}$ glucose per liter of water) was summated to a centrifuge tube. The obtained sediment was reslinged, in which both sides of the McMaster counter chamber were permeated. The full filled McMaster chamber was stabilized for 180 to 300 seconds prior to the counting procedure. The EPG was calculated by multiplying the total number of eggs within the McMaster slide, as described previously (12). The observed helminth eggs visualized were determined via standard parasitological criteria (13). EPG counts were solely detected immediately prior to treatment applications and 10 days thereafter, following the albendazol prescription (Figure 1).

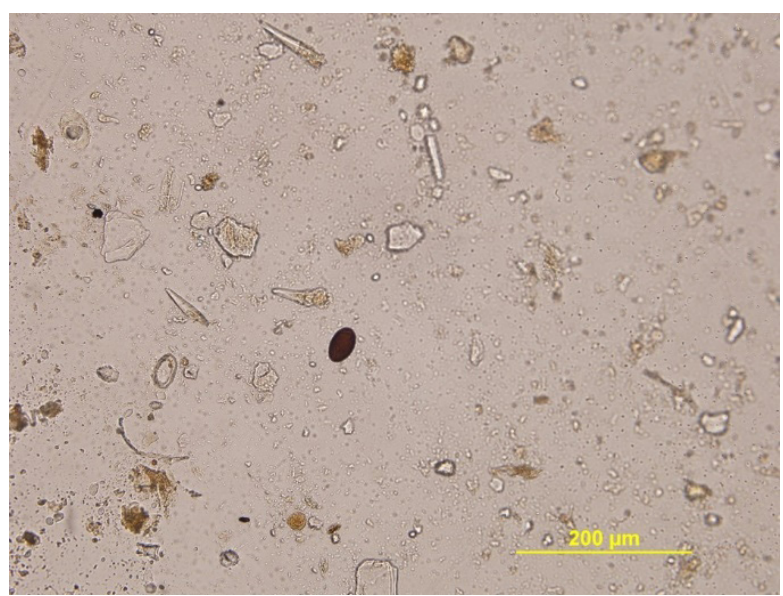

Figure 1. Dicrocelium sp. egg in feaces. (McMaster technique)

Statistical analyses. Descriptive statics were obtained and homogeneity tests were performed and Statistical evaluation of PT, APT'T and fibrinogen values before and after treatment were performed with non-parametric Wilcoxon test. All statistical analyses were carried out using SPSS Software Ver. 21 (IBM, Chicago, IL, USA), $\mathrm{p}<0.05$ was considered significant. 


\section{RESULTS}

Egg output and microscopic positivity was recorded in all 34 sheep. Prior to treatment, EPG ranged from 4.000 to 12.000. After treatment, eggs were detected in only one of the 34 sheep. One hundred EPG were found in this sheep.

Clinical recovery was achieved in animals after albendazol administration, as detected by the authors (Erdogan, Ural, and Pasa) on field examination performed on a weekly basis for twice. No side effects due to albendazole administration were observed.

Regarding coagulation parameters there were significant differences $(\mathrm{p}=0.001, \mathrm{p}=0.00)$ observed in median values of PT and fibrinogen before and after treatment, while no significant difference was observed in APT'T values (Table 1)
Extensions in PT might be determined by using sensitive thromboplastin reagents in these patients. Fibrinogen concentration in frequently increases to those of cases with liver injury $(16,18)$. Prothrombin time (PT), foremost prognostic biomarker of prediction among acute liver failure cases who are candidates for liver transplantation. Fibrinogen and factor VIII, similar to relevant acute phase biomarkers elevated, and their gradual decline should denote existence of DIC. Assoicated liver cirrhosis causes decreased procoagulant factor concentrations. On the other hand, to those of compensated liver cirrhosis PT frequently is within in the reference intervals or cautioulsy prolonged, and fibrinogen concentration remains normal (17). Although the severity of parasitic infestations in sheep in the present study was not striking, statistically significant alterations in PT and fibrinogen levels were observed. Theodoridis et al (19), has been reported no significant blood or plasma protein loss in sheep infected with up to $4000 \mathrm{D}$. dendriticum worms, which

Table 1. PT, APT'T and fibrinogen values in sheep $(\mathrm{n}=34)$ naturally infected with Dicrocoelium dentriticum before and 10 days after treatment with albendazole $(15 \mathrm{mg} / \mathrm{kg})$

\begin{tabular}{llll}
\hline Parameters & Before treatment $(\mathrm{n}=34)$ & After Treatment $(\mathrm{n}=34)$ & p-value* \\
\hline PT $(\mathrm{sec})$ & & & \\
Median & 24.77 & 15.28 & 0.001 \\
SE & 1.66 & 2.62 & \\
APTT(sec) & & & 0.393 \\
Median & 43.59 & 57.37 & \\
SE & 2.37 & 15.92 & \\
Fibrinogen (mg/dl) & & & 0.00 \\
Median & 348.27 & 133.52 & \\
SE & 17.90 & 20.04 & \\
\hline
\end{tabular}

*Wilcoxon test, significance p<0,05, SE: Standard Error of Mean, PT: Prothrombin time, APTT: Activated Partial Thromboplastin Time

\section{DISCUSSION}

Some parasites in domestic animals and particularly in ruminants such as Schistosoma bovis are potential causes of haemostatic disorders. This parasite shows fibrinolytic activity by utilizing the proteins, namely annexin, to make haemostatic changes such as bleeding diathesis and anticoagulant properties (14). Similarly, there are protein constructs on D. dentriticum that also provide a way to regulate RNAase digestion and host-parasite interaction in body fluids (15). These proteins provide a way to regulate host-parasite interplay and increases the severity of liver damage. Haemostatic disorders that cause bleeding may occur by in cases of hepatitis and are in a clearly correlated with the deterioration of the liver parenchymal cell. No changes are observed in patients with mild hepatitis however there may be slight decreases in factor VII and vitamin K-related factors (factor II, XI, and X) (16). One of the most important organ, liver has well known for its participant role for exitence of coagulation factors, excluding vWF. Taking into account debit of procoagulants due to declined synthesis capacity of liver, might be related to the degree of injury, and thus the prognosis (17). might succinctly explain worm burden and related alterations in the gastrointestinal system or coagulation disorders.

Pro-benzimidazole and benzimidazole drugs especially albendazole and netobimin were recommended for controlling D. dentriticum infections at different doses between 7.5 and $15 \mathrm{mg} / \mathrm{kg}$ orally (20). Abdouslam et al. (21), reported no significant changes in PT, APTT, or fibrinogen levels in llamas treated with albendazole to control mixed gastrointestinal parasites. They explained this situation by the lower levels of parasitic infection in the study animals.

In the present study, increased fibrinogen concentrations prior to albendazol treatment might have indicated activation of the coagulation system and potential fibrin formation (22). Elevated fibrinogen concentrations prior to treatment intervention, could have interfered with the process of antigens binding to antibodies (23), which might be capable of suppressing the immune system, similar findings were described for prolonged Babesia survival in the circulatory system of dogs (24). The interaction between elevated 
fibrinogen levels and the immune system must be discussed in depth. During infections that trigger multible responses, coagulation might be involved. Among different disorders coagulation in relationship with inflammation halt invading etiological agents. Innate immune system in respond to pathogens might also induce coagulation. Contrarily, the protein and cellular compartments of the immune response took role within several disorders. Therefore it should not be unwise to draw conclusion that coagulation within the vast majority should be a component of the innate immune respond (25).

In every day practice, fibrinogen is a component of the coagulation cascade, which repairs the inner walls of the blood vessels. Liver failure can alter production of fibrinogen concentration, and it could be suggested that the increased fibrinogen concentration should indicates inflammation in the liver, as was the case in the present study due to parasitic infection. Another explanation could involve fibrinogen, also an acute phase protein, which is expected to be increased in cases of inflammation or infection in ruminants (26). In all animal species, fibrinogen elevation begins within one day of tissue injury. However, fibrinogen responses vary from species to species and are frequently related to the degree of inflammation. Fibrinogen levels increases in acute disease, whereas in an appropriate responses, they quickly returns to normal. In chronic conditions, the fibrinogen concentratations rise and remain at increased levels as long as the underlying disease remains (26).

It might be appropriate to draw the conclusion that a protective immune response may exists with interaction against multiple parasitic infections (27). Gastrointestinal nematodes may induce a significant immune response in ruminants, leading to protection from subsequent exposure (28). Hence host immune alterations affect the existence of parasitic infections and may have helped protection against relevant negative effects, (28). The resistance and entire significance of host immune alterations differ among and within species of host (29). Beck et al. (30), argued that beef cattle herding on a co-grazed pasture caused the transmission of a significant percentage of the 300 billion $D$. dendriticum eggs that are thought to contaminate Canadaian pasture. When comparing the results obtained from the present, study there was a significant decrease on fibrinogen levels which might be attributed to aforementioned data.

It is also important to note that this study is also limited by the lack of validation of the analytic performance of the coagulometer for sheep blood. The present authors were unable to locate documented reports regarding hemostatic alterations. A few limited studies have reported coagulation parameters in sheep plasma. In one of these studies, researchers investigated whether Fasciola hepatica alters coagulation parameters in sheep plasma in vivo and in vitro (31). The researchers suggested that F. hepatica comprises mediators that contribute to coagulation changes in vivo. Another study focused on interspecies differences in coagulation profiles, and the endogenous thrombin potential revealed comparable ranges in sheep and humans (32). In the first study, rotation thromboelastometry (ROTEM) was preferred fpr analysis; in the second, plasma coagulation (APT'T, PT, TT, and single clotting factor assays) standard ball coagulometer (Sigma, Germany) were preferred for analysis. Although it is not very easy to compared different methodologies, as far as to the present authors' knowledge no previous study reported validation for the Beijing Precise semi-automated coagulometer, which would be the aim of our subsequent study.

For the authors knowledge, no studies were found validation of the analytic performance of semiautomated coagulometers. Different studies should be undertaken to evaluate the analytical performance of coagulometry. The present study is limited because of the selected population of sheep, for which it is well understood that it is difficult to obtaining statistically true/number of samples validation (33).

The other detection limits of the present study has to briefly discussed. The present study was carried out with well recognized clinical practice standards. Rigorous inclusion and exclusion criteria were deemed available prior to the trial to ensure, a presumptive diagnosis of dicroceoliasis. Furthermore the diagnosis, however, was not challenging, as a well practiced parasitology specialist was involved within this study. In particular, it was also possible to withdraw other parasitological conditions interfere within this study. Selection bias in breed, age, sex and weight was not apparent, as this study was not an experimental one. Detection bias by the investigator was, however, likely as this was an open label field study. Performance bias was not thought to exist as solely one compound was preferred for treatment. Attrition bias was no evident as no animal was withdrawn. It is possible that this biased towards an expected and well response to treatment, as in our study, we found significant reduction in PT times and fibrinogen values after albendazole treatment. This should be briefly explained by the normalisation of haemostasis, as was also defined by Schulman et al. (34). On the other hand someone may speculate the results we obtained in which differences were observed in PT and not in APTT. This may be related to probable disseminated intravascular coagulation, some of the animals presented unaltered APT'T levels

In conclusion, the objective of this study was to evaluate the coagulation profile, with the use of selected parameters, in sheep naturally infected with $D$. dentriticum and to investigate the effect of treatment. Our results suggest that moderate changes might occur within the coagulation parameters among D. dentriticum infected sheep. Obtained alterations available within his study might be dedicated to the pro-coagulatory efficacy of the etiological capable of a) extensive damage in the liver through penetration to the bile ducts, b) irritation within the bile ducts, c)infectious hepatitis or d) free radicals displaying a pivotal role within in the pathogenesis of parasitic infections (35) which counteract with macromolecules and nucleic acids resulting with dysfunction of cellular matrix namely oxidative stress. It has been well established that oxidative stress, inflammation and coagulation have all been engaging. 


\section{ACKNOWLEDGEMENTS}

The researchers who put pen and great effort were involved to this study. This research did not receive any specific grant from funding agencies in the public, commercial, or not-forprofit sectors.

\section{REFERENCES}

1. Soulsby EJL, Helminths A. Protozoa of Domesticated Animals. 6th ed. UK: Baillière Tindall; 1982.

2. Ranucci S, Mughetti L, Ambrosi M, Grelloni V. Rilievi ematochimici, anatomo-istopatologici e parassitologici in ovini infetti da dicroceliosi. Rev Zoo Vet. 1981;9:173-175.

3. Otranto D \& Traversa D. A review of dicrocoeliosis of ruminants including recent advances in the diagnosis and treatment. Vet Parasitol. 2002;107:317-335.

4. Manga-González MY, Ferreras MC, Campo RC, González-Lanza Pérez V, García-Marín JF. Hepatic marker enzymes, biochemical parameters and pathological effects in lambs experimentally infected with Dicrocoelium dendriticum. Parasitol Res. 2004;93: 344-355.

5. Kavanagh C, Shaw S, Webster CR. Coagulation in hepatobiliary disease. J Vet Emerg Crit Care. 2011;21:589-604.

6. Anstee QM, Wright M, Goldin R, Thursz MR. Parenchymal extinction: coagulation and hepatic fibrogenesis. Clin Liver Dis. 2009;13:117-126.

7. Lisman T, Caldwell SH, Burroughs AK, Northup PG, Senzolo M, Stravitz RT. Hemostasis and thrombosis in patients with liver disease: the ups and downs. J Hepatol. 2010;53:362-371.

8. Manga-González MY, Ferreras MC. Dicrocoeliidae family: major species causing veterinary diseases. Adv Exp Med Biol. 2014;766: 393-428.

9. Coma SM, Bargues MD. Human liver flukes: a review. Res and Rev Parasito. 1997;57:145-218.

10. Coma SM, Agramunt VH, Valero MA. Neurological and ocular fascioliasis in humans. Adv Parasitol. 2014;84:27149.

11. Wilhelmi MH, Tiede A, Teebken OE, Bisdas T, Haverich A, Mischke R. Ovine blood: Establishment of a list of reference values relevant for blood coagulation in sheep. ASAIO Journal. 2012;58:79-82.

12. Naeemipour M, Hashemitabar GR, Dastjerdi K, Mojaver MJ, Mohammadi HR. Comparison of Fecal Egg Counts and ELISA for the diagnosis of Dicrocoelium Dendriticum infection. Pol J Vet Sci. 2016; 19(3): 573-580.

13. Roepstorff A \& Nansen P. Epidemiology, diagnosis and control of helminth parasites of swine. Rome: FAO Animal Health Manual; 1998.

14. Torre-Escudero ER, Manzano-Román M, Siles-Lucas R, Pérez-Sánchez JC, Moyano I, Barrera AO. Molecular and functional characterization of a Schistosoma bovis annexin: fibrinolytic and anticoagulant activity. Vet Parasitol. 2012, 184:25-36.

15. Bernal D, Trelis M, Montaner S, Cantalapiedra F, Galiano A, Hackenberg M. Surface analysis of Dicrocoelium dendriti- cum: The molecular characterization of exosomes reveals the presence of miRNAs. J Proteomics. 2014;105:232-241.

16. Mammen EF. Coagulation defects in liver disease. Med Clin North Am. 1994;78:545-554.

17. Amitrano L, Guardascione MA, Brancaccio V, Balzano A. Coagulation disorders in liver disease. Semin. Liver Dis. 2002;22:83-96.

18. Caldwell SH, Hoffman M, Lisman T, Macik BG, Northup PG, Reddy KR. Coagulation disorders and hemostasis in liver disease: pathophysiology and critical assessment of current management. Hepatol. 2006;44:1039-1046.

19. Theodoridis Y, Duncan JL, Maclean JM, Himonas CA. Pathophysiological studies on Dicrocoelium dendriticum infection in sheep. Vet Parasitol. 1991;39:61-66.

20. Rojo-Vázquez FA, Meana A, Valcárcel F, Martínez-Valladares M. Update on trematode infections in sheep. Vet Parasitol. 2012;189:1538.

21. Abdouslam OE, Al-1zzi SA, Al-bassam LS, Azwai SM. Effect of anthelmintic treatment on haematological and coagulation parameters in Ilamas (Lama glama) Infected with gastrointestinal parasites. J Camel Pract Res. 2003;10:149152.

22. Schetters TP, Kleuskens JAGM, Crommert VJ, Leeuw PWJ, Finizio AL, Gorenflot A. Systemic inflammatory responses in dogs experimentally infected with Babesia canis; a haematological study. Vet Parasitol. 2009;162: 7-15.

23. Boehm TK, Sojar H, De Nardin E. Concentration-dependent effect of fibrinogen on IgG-specific antigen binding and phagocytosis. Cellular Immuno. 2010;263:41-48.

24. Rafaj BR, Kuleš J, Selanec J, Vrkić N, Zovko V, Zupančič M. Markers of coagulation activation, endothelial stimulation, and inflammation in dogs with babesiosis. J Vet Intern Med. 2013; 27:1172-1178.

25. Esmon CT, Xu J, Lupu F. Innate immunity and coagulation. J Thromb Haemost. 2011;9:182-188.

26. Gånheim C, Hulten C, Carlsson U, Kindahl H, Niskanen $\mathrm{R}$, Waller KP. The acute phase response in calves experimentally infected with bovine viral diarrhoea virus and/or Mannheimia haemolytica. Zoonoses Public Health. 2003; 50:183-190.

27. Van Der Ree AM, Mutapi F. The helminth parasite proteome at the host-parasite interface-Informing diagnosis and control. Exp Parasitol. 2015;157:48-58.

28. Knox MR, Besier RB, Le Jambre LF, Kaplan RM, Torres-Acosta JFJ, Miller J. Novel approaches for the control of helminth parasites of livestock VI: Summary of discussions and conclusions. Vet Parasitol. 2012;186:143-149.

29. Colditz IG. Effects of the immune system on metabolism: implications for production and disease resistance in livestock. Livest Sci. 2002;75:257-268.

30. Beck MA, Goater CP, Colwell DD. Comparative recruitment, morphology and reproduction of a generalist trematode, Dicrocoelium dendriticum, in three species of host. Parasitology. 2015;142:1297-1305.

31. Joachim A, Ali S, Daugschies A. Fasciola hepatica alters coagulation parameters in sheep plasma in vivo and in vit- 
ro. Parasitol Res. 2002;89:53-58.

32. Matula SJM, Plasenzotti R, Spiel A, Quehenberger P, Jilma B. Interspecies differences in coagulation profile. Thromb Haemost. 2008;100:397-404.

33. Gardiner C, Adcock DM, Carrington LR, Kottke MK, Marlar RA, McGlasson DL. Protocol for the Evaluation, Validation, and Implementation of Coagulometers; Approved Guideline H57-A. Clinical and Laboratory Standards Institute. 2008.

34. Schulman S, Elbazi R, Zondag M, O’Donnell M. Clinical factors influencing normalization of prothrombin time after stopping warfarin: a retrospective cohort study. Thromb J. 2008;6:15.

35. Oliveira FJA, Cechini R. Oxidative stress of liver in hamsters infected with Leishmania (L.) chagasi. J Parasitol. 2002;86:1067-1072. 